\title{
Correlation of fine needle aspiration cytology with histopathology for thyroid swellings in a tertiary care hospital in South India
}

\author{
C. Pereira, D. Rohan, L.F. Tauro \\ Father Muller Medical College \\ India, Karnataka, 575002 Mangalore, Father Muller rd.
}

\begin{abstract}
Fine needle aspiration cytology (FNAC) is documented to be a good tool in the diagnosis of thyroid lesions. It has good diagnostic accuracy and is an inexpensive investigation. Although a good instrument it does have its own limitations especially when it comes to distinguishing a follicular adenoma from follicular carcinoma thyroid. Objectives of the study was the evaluation of FNAC in the diagnosis of thyroid lesions by determining its sensitivity, specificity, diagnostic accuracy, positive predictive value and negative predictive value. Material and methods. This is a retrospective study of 580 cases of thyroid swelling admitted to our hospital and undergone thyroidectomy over a period of 5 years from 2015 to 2020. After thyroidectomy, FNAC reports (Bethesda system for reporting) of those patients were collected and were compared and analyzed with the histopathology reports. Category 1 and category 3 cases were excluded from calculation due to uncertainty in reporting. Data were analyzed to calculate the sensitivity, specificity, diagnostic accuracy, positive predictive value and negative predictive value of FNAC. Results. Our study included a total of 580 cases of thyroid swellings. The male to female ratio was 1:18.2 and the median age was 43 years. On FNAC, 428 cases $(73.7 \%)$ were benign, 35 cases $(6 \%)$ were indeterminate, 39 cases $(6.7 \%)$ were follicular neoplasm, 30 cases $(5.1 \%)$ were suspicious for malignancy and $34(5.8 \%)$ were malignant. $14(2.4 \%)$ cases were unsatisfactory. Cytology report was then compared with histopathological reports. FNAC had a sensitivity of $84.2 \%$, specificity of $97.2 \%$ and a diagnostic accuracy of $94.5 \%$. The positive predictive value and negative predictive value were 88.3 and $96 \%$ respectively. Conclusions. FNAC is a more specific than sensitive when distinguishing between benign and malignant lesions of thyroid. It has good diagnostic accuracy and hence should be used in all tertiary care hospitals prior to surgery in diagnosing thyroid lesions.
\end{abstract}

Key words: thyroid, FNAC, thyroid carcinoma, papillary carcinoma, Bethesda category.

Conflict of interest. All authors declare that there is no conflict of interest.

Source of funding: nil.

Correspondence author: Pereira C., e-mail: chiggy1989@gmail.com

Citation: Pereira C., Rohan D., Tauro L.F. Correlation of fine needle aspiration cytology with histopathology for thyroid swellings in a tertiary care hospital in South India. Sibirskiy nauchnyy meditsinskiy zhurnal = Siberian Scientific Medical Journal. 2020; 40 (5): 79-83. doi: 10.15372/SSMJ20200509

\section{Сравнение метода тонкоигольной аспирационной цитологии с гистопатологией у пациентов с разрастанием щитовидной железы в больнице третичного уровня в Южной Индии}

\author{
C. Pereira, D. Rohan, L.F. Tauro \\ Father Muller Medical College \\ India, Karnataka, 575002 Mangalore, Father Muller rd.
}

\section{Резюме}

Подтверждено, что тонкоигольная аспирационная цитология (ТАЦ) является хорошим методом диагностики повреждений щитовидной железы. Метод имеет высокую диагностическую точность и недорогой. Несмотря на вышеперечисленное у него есть свои ограничения, особенно при отличии фолликулярной аденомы от фолликулярной карциномы щитовидной железы. Целями исследования была оценка ТАЦ в диагностике повреждений 
щитовидной железы путем определения его чувствительности, специфичности, диагностической точности, положительной прогностической ценности и отрицательной прогностической ценности. Материал и методы. Проведено ретроспективное исследование 580 случаев разрастания щитовидной железы, перенесших тиреоидэктомию в течение 5 лет с 2015 по 2020 гг. У пациентов после тиреоидэктомии анализы ТАЦ (система отчетности Bethesda) сравнивали и проанализировали с отчетами гистопатологии. Случаи категории 1 и категории 3 были исключены из расчета из-за неопределенности в отчетности. Данные были проанализированы для расчета чувствительности, специфичности, диагностической точности, положительной прогностической ценности и отрицательной прогностической ценности ТАЦ. Полученные результаты. В исследование были включены 580 пациентов с разрастанием щитовидной железы. Соотношение мужчин и женщин составляло $1: 18,2$, а средний возраст - 43 года. По результатам ТАЦ 428 случаев (73,7 \%) были доброкачественными, 35 случаев (6 \%) были неопределенными, 39 случаев (6,7 \%) были фолликулярными новообразованиями, 30 случаев $(5,1 \%)$ были подозрительными на злокачественные новообразования и 34 (5,8 \%) были злокачественными. 14 (2,4 \%) случаев были неудовлетворительными. Затем цитологический отчет сравнивали с гистопатологическим отчетом. ТАЦ имел чувствительность 84,2 \%, специфичность 97,2 \% и диагностическую точность 94,5 \%. Прогнозирующая ценность положительного и отрицательного прогнозов составила 88,3 и 96 \% соответственно. Выводы. При отличии доброкачественных и злокачественных поражений щитовидной железы ТАЦ более специфичен, чем чувствителен. Метод имеет хорошую диагностическую точность и, следовательно, должен использоваться во всех больницах перед операцией для диагностики поражений щитовидной железы.

Ключевые слова: щитовидная железа, тонкоигольная аспирационная цитология, карцинома щитовидной железы, папиллярная карцинома, категория Bethesda

Конфликт интересов. Авторы заявляют об отсутствии конфликта интересов.

Автор для переписки: Pereira C., e-mail: chiggy1989@gmail.com

Для цитирования: Pereira C., Rohan D., Tauro L.F. Сравнение метода тонкоигольной аспирационной цитологии с гистопатологией у пациентов с разрастанием щитовидной железы в больнице третичного уровня в Южной Индии. Sibirskiy nauchnyy meditsinskiy zhurnal = Siberian Scientific Medical Journal. 2020; 40 (5): 79-83. doi: 10.15372/SSMJ20200509

\section{Introduction}

Thyroid swellings are quite common in the general population and predominantly affect women as compared to men. Based on a study conducted in south India, thyroid swellings can be clinically detected in about 12 percent of adult population [1]. There are numerous etiologies for thyroid swellings and this is commonly classified as either benign or malignant. It is important to distinguish between the two since the modality of treatment varies considerably. Hence, the aim of investigations is not only to determine the cause of thyroid swelling but also to rule out malignancy [2]. Approximately $5 \%$ of individuals with thyroid swellings are found to have malignant nodules [3]. In India, 5-6\% of thyroid cancers occur in women and $2 \%$ are seen in men [4].

It is essential to have a good diagnostic tool in order to diagnose patients with malignancy. Not all patients with thyroid swelling require surgery and furthermore a good diagnostic tool will help surgeons decide the extent of surgery that needs to be performed. Hence, these tests play a crucial role in deciding the treatment of patients [5]. Thyroid gland being a relatively superficial swelling makes it amiable to clinical examination, fine needle aspiration cytology (FNAC) and even trucut biopsy in few specialized centers. Trucut biopsy of thyroid gland is not routinely performed since it increases chances of damage to structures like the recurrent laryngeal nerve and thyroid vasculature. Hence, FNAC is more commonly utilized for diagnosis. It is a simple, quick and relatively cheap procedure easily done in the Out-Patient Department. It is a good investigation to determine the etiology of thyroid swelling and differentiate a benign from a malignant thyroid lesion [6]. Published data shows that the accuracy of FNAC diagnosing a malignant thyroid lesion is more than $90 \%[7,8]$.

One of the short comings of FNAC is its inability to distinguish follicular adenoma from carcinoma [9]. Other limitations include misdiagnosis of Hashimoto thyroiditis and follicular and Hurthle cell adenomas are wrongly classified as papillary carcinomas on numerous occasions [9-11]. These limitations are due to inadequate sampling, improper technique, skill of the pathologist/physician performing the aspiration and experience of the pathologist interpreting the results [12]. The main aim of our study is to determine the effectiveness of FNAC in the diagnosis of various thyroid lesions by calculating the specificity and sensitivity of FNAC. 


\section{Material and Methods}

This is a retrospective study of 580 diagnosed cases of thyroid swelling that presented to the general surgery, surgical oncology and Ear, Nose and Throat Out-Patient Departments of Father Muller hospital in the period between January 2015 and December 2019. All case notes were retrieved using our hospital computer data system. Age, sex, cytological and histological diagnosis were reviewed. Diagnosis of cytological smears was done using Bethesda system of reporting. According to this system, reports were classified as follows: category 1 - non-diagnostic or unsatisfactory, category 2 - benign, category 3 - atypia of undetermined significance / follicular lesion of undetermined significance, category 4 - follicular neoplasm, category 5 - suspicious for malignancy, category 6 - malignant.

FNAC results were then compared with histopathology reports to calculate the sensitivity, specificity, positive and negative predictive value of FNAC in diagnosing thyroid lesions. Category 1 and Category 3 cases were excluded from calculations since it's difficult to classify them as benign or malignant based on FNAC.

\section{Results}

A total of 580 patients were included in our study. Total number of males was 90 and the total number of females was 490 , with female to male ratio being $18.3: 1$. In our study the age ranged from 16 to 78 years, with the median age being 43 years.

On interpretation of FNAC the following results were obtained. There were 428 benign cases (73.7\%), atypia/follicular lesion of undetermined significance in 35 cases $(6 \%)$, follicular neoplasm included 39 cases $(6.7 \%)$, suspicious for malignancy included 30 cases $(5.1 \%)$ and lastly confirmed malignancy were 34 cases $(5.8 \%)$. The total number of unsatisfactory cases was $14(2.4 \%)$. The benign diagnosis included 405 cases $(94.6 \%)$ of nodular colloid goiter and 23 cases $(5.3 \%)$ of Hashimoto thyroiditis. The malignant diagnosis: 31 cases $(91.9 \%)$ of papillary thyroid cancer, 2 cases $(5.8 \%)$ of medullary thyroid cancer and 1 case $(2.9 \%)$ of anaplastic cancer.

The FNAC reports were then compared with the histopathology report after patients underwent surgery. Of the 405 cases diagnosed as benign swellings on FNAC, there were 369 (91.1\%) cases of nodular colloid goiter (true negative, TN), $42(10.3 \%)$ cases of Hashimoto thyroiditis (TN), 5 (1.2\%) cases of follicular adenoma (false negative, FN), 9 $(2.2 \%)$ cases of papillary carcinoma thyroid (FN) and $3(0.7 \%)$ cases of follicular carcinoma thyroid
(FN). In our study, 7 (17.9\%) cases of follicular neoplasm were diagnosed as nodular goiter (false positive, FP), $1(2.6 \%)$ case as Hashimoto thyroiditis (FP), $3(7.7 \%)$ cases of Hurthle cell carcinoma (true positive, TP), 7 (17.9\%) cases as papillary thyroid cancer (TP), 13 (33.3\%) cases of follicular adenoma (TP) and $8(20.5 \%)$ cases of follicular thyroid cancer (TP). Of the 30 cases suspicious for malignancy, there were $26(86.7 \%)$ cases of papillary thyroid cancer (TP), $1(3.3 \%)$ case of Hashimoto thyroiditis (FP) and $3(10 \%)$ cases of nodular goiter (FP). Among the 34 confirmed malignancies, there were $2(5.8 \%)$ cases of medullary carcinoma thyroid (TP), $1(2.9 \%)$ case of anaplastic carcinoma thyroid (TP) and $31(91.1 \%)$ case of papillary carcinoma thyroid (TP).

$35(6 \%)$ cases out of 580 were diagnosed as category 3 , of which $11(31.4 \%)$ cases were follicular lesion of undetermined significance and $24(68.6 \%)$ cases showed atypia of undetermined significance. On histopathological examination, there were 4 (11.4\%) cases of follicular adenoma, $2(5.7 \%)$ cases of Hashimoto thyroiditis, 18 (51.4\%) cases of nodular colloid goiter, $2(5.7 \%)$ cases of follicular thyroid carcinoma and $9(25.7 \%)$ cases of papillary thyroid cancer.

Of the 428 cases diagnosed cytologically into category 1, $411(96 \%)$ cases were non neoplastic (TN) while 17 (4\%) cases were diagnosed to be neoplastic after histopathology (FN). Out of 39 cases of follicular neoplasm, 31 (79.5\%) cases were TP. Among the 64 included suspicious and malignant cases, 60 (93.8 \%) cases were confirmed to be malignant (TP) while $4(6.2 \%)$ cases were benign after histopathological examination (FP).

Hence, FNAC achieved a sensitivity of $84.2 \%$, specificity of $97.1 \%$, and a total accuracy of $94.8 \%$. The positive predictive value and negative predictive value were 88.3 and $96 \%$ respectively.

\section{Discussion}

Numerous studies have demonstrated that among various modalities for diagnosing thyroid swellings, FNAC stands out to be a safe, accurate and less expensive tool [13]. Although a good tool it does have few limitations. If the sampling of the specimen is inadequate diagnosis becomes very difficult. Another major limitation is its inability to distinguish a benign follicular swelling from a malignant one. As with all investigation FNAC can show false positive and negative results mainly with small swellings and when thyroid nodules are associated with inflammation or degeneration. For example, distinguishing a nodular colloid goiter from a follicular neoplasm may be impossible [14]. Thyroid swellings are quite common 
in India with $12 \%$ of the population presenting with clinically palpable masses [1].

Thyroid swellings are commonly seen in females but the incidence of thyroid cancer in females is less as compared to males. Numerous studies have shown that the female to male ratio for thyroid swellings is $5: 1$ [15-17]. Male patients were found to have malignancy rates ranging from 19 to $26 \%[15,17]$. In our study there were larger number of females as compared to males with a female to male ratio of 18.3:1. The median age was 43 and the ages ranged from 16 to 78 years.

In our study cases diagnosed with thyroid malignancy ranged from 20 to 77 years with the median age being 44. There were larger number of benign cases in our study as compared to malignant and this was similar to other published literature $[18,19]$. The most common benign lesion encountered in our study was nodular colloid goiter while the most common malignant lesion was papillary carcinoma of the thyroid followed by follicular carcinoma. We encounter only one case of anaplastic carcinoma in our study.

As stated earlier, inadequate sample size makes diagnosis by FNAC a difficult task. In published data inadequate sample size ranges between 2 to $20 \%$ [20]. In our study this rate was $2.4 \%$. Percentage of cases showing follicular lesion of undetermined significance and atypia of undetermined significance were 1.8 and $4.1 \%$ respectively. This is comparable with published literature where the percentage ranges between 2-6\% [21]. Sinna et al. [18] found a much higher percentage of follicular lesion of undetermined significance on FNAC which is $13.5 \%$. They attributed this due to varied impression of FNAC by different cytopathologist especially when diagnosing category 3 cases on FNAC.

In our study FNAC has a sensitivity of $84.2 \%$, specificity of $97.2 \%$ and a diagnostic accuracy of $94.5 \%$. The positive predictive value was $88.3 \%$ and the negative predictive value was $96 \%$. Sensitivity, specificity and diagnostic accuracy were comparable to other studies done by Basharat et al. [22] and Kessler et al. [23]. We calculated the FP rate and FN rate for our study. FN rate is the percentage of patients found to have malignant thyroid lesions on histopathology while their FNAC earlier was reported as benign. In our study FN rate was $15.7 \%$. Our value was relatively higher as compared to a series of studies where FN rate was reported to range from 1.5 to $11.5 \%$ [24]. The FP rate indicates that a patient with malignant FNAC result was found on histological examination to have benign lesion. The FP rate in our study was $2.8 \%$ which was comparable to published literature [24, 25].

\section{Conclusion}

FNAC is a more specific than sensitive when distinguishing between benign and malignant lesions. It has good diagnostic accuracy and hence should be used in all tertiary care hospitals prior to surgery to diagnose thyroid lesions.

\section{References}

1. Usha Menon V., Sundaram K.R., Unnikrishnan A.G., Jayakumar R.V., Nair V., Kumar H. High prevalence of undetected thyroid disorders in an iodine sufficient adult south Indian population. J. Indian Med. Assoc. 2009; 107 (2): 72-77.

2. Yeung M.J., Serpell J.W. Management of the solitary thyroid nodule. Oncologist. 2008; 13 (2): 105112. doi: 10.1634/theoncologist.2007-0212

3. Belfiore A., La Rosa G.L., La Porta G.A., Giuffrida D., Milazzo G., Lupo L., Regalbuto C., Vigneri R. Cancer risk in patients with cold thyroid nodules: relevance of iodine intake, sex, age, and multinodularity. Am. J. Med. 1992; 93 (4): 363-369. doi: 10.1016/00029343(92)90164-7

4. Unnikrishnan A.G., Menon U.V. Thyroid disorders in India: An epidemiological perspective. Indian J. Endocrinol. Metab. 2011; 15 (Suppl 2): S78-81. doi: $10.4103 / 2230-8210.83329$

5. Dean D.S., Gharib H. Fine-needle aspiration biopsy of the thyroid gland. [Updated 2015 Apr 26]. In: Endotext [Internet]. Eds. K.R. Feingold, B. Anawalt, A. Boyce et al. South Dartmouth: MDText.com, 2000-. Available at: https://www.ncbi.nlm.nih.gov/books/NBK 285544/

6. Menon S.S., Tandon P., Ramaswamy B., Pujary K. A retrospective study to assess the role of Using fine needle aspiration cCytology and frozen section in the diagnosis of thyroid swelling. Indian J. Otolaryngol. Head Neck Surg. 2018; 70 (4): 471-476. doi: 10.1007/s12070-018-1503-4

7. Bista M., K C.T., Regmi D., Maharjan M., Kafle P., Shrestha S. Diagnostic accuracy of fine needle aspiration cytology in thyroid swellings. J. Nepal Health Res. Counc. 2011; 9 (1): 14-16.

8. Bagga P.K., Mahajan N.C. Fine needle aspiration cytology of thyroid swellings: how useful and accurate is it? Indian J. Cancer. 2010; 47 (4): 437-442. doi: 10.4103/0019-509X.73564

9. Liu F.H., Liou M.J., Hsueh C., Chao T.C., Lin J.D. Thyroid follicular neoplasm: analysis by fine needle aspiration cytology, frozen section, and histopathology. Diagn. Cytopathol. 2010; 38 (11): 801-805. doi: $10.1002 /$ dc. 21294

10. Almeida J.P., Couto Netto S.D., Rocha R.P., Pfuetzenreiter E.G., Jr., Dedivitis R.A. The role of intraoperative frozen sections for thyroid nodules. Braz. J. Otorhinolaryngol. 2009; 75 (2): 256-260. doi: 10.1016/ s1808-8694(15)30787-4 
11. Lumachi F., Borsato S., Tregnaghi A., Marino F., Polistina F., Basso S.M., Koussis H., Basso U., Fassina A. FNA cytology and frozen section examination in patients with follicular lesions of the thyroid gland. Anticancer Res. 2009; 29 (12): 5255-5257. doi: 29/12/5255 [pii]

12. Baloch Z.W., Sack M.J., Yu G.H., Livolsi V.A., Gupta P.K. Fine-needle aspiration of thyroid: an institutional experience. Thyroid. 1998; 8 (7): 565-569. doi: 10.1089/thy.1998.8.565

13. Caruso D., Mazzaferri E.L. Fine needle aspiration biopsy in the management of thyroid nodules. The Endocrinologist. 1991; 1 (3): 194-202.

14. Hall T.L., Layfield L.J., Philippe A., Rosenthal D.L. Sources of diagnostic error in fine needle aspiration of the thyroid. Cancer. 1989; 63 (4): 718-725. doi: $\quad 10.1002 / 1097-0142(19890215) 63: 4<718$ ::aidcncr2820630420>3.0.co;2-n

15. Haugen B.R., Alexander E.K., Bible K.C., Doherty G.M., Mandel S.J., Nikiforov Y.E., Pacini F., Randolph G.W., Sawka A.M., Schlumberger M., Schuff K.G., Sherman S.I., Sosa J.A., Steward D.L., Tuttle R.M., Wartofsky L. 2015 American Thyroid Association management guidelines for adult patients with thyroid nodules and differentiated thyroid cancer: The American Thyroid Association guidelines task force on thyroid nodules and differentiated thyroid cancer. Thyroid. 2016; 26 (1): 1-133. doi: 10.1089/ thy. 2015.0020

16. Huber G.F., Dziegielewski P., Matthews T.W., Warshawski S.J., Kmet L.M., Faris P., Khalil M., Dort J.C. Intraoperative frozen-section analysis for thyroid nodules: a step toward clarity or confusion? Arch. Otolaryngol. Head Neck Surg. 2007; 133 (9): 874-881. doi: 10.1001/archotol.133.9.874

17. Batra C., Singh S., Katra R., Marwah N., Atreja A. Role of fine needle aspiration and frozen section in the diagnosis of thyroid lesions. The Internetional
Journal of Pathology. 2010; 11 (1): Available at: http:// ispub.com/IJPA/11/11/5705.

18. Sinna E.A., Ezzat N. Diagnostic accuracy of fine needle aspiration cytology in thyroid lesions. J. Egypt Natl. Canc. Inst. 2012; 24 (2): 63-70. doi: 10.1016/j. jnci.2012.01.001

19. Menon S.S., Tandon P., Ramaswamy B., Pujary K. A retrospective study to assess the role of using fine needle aspiration cytology and fozen section in the diagnosis of thyroid swelling. Indian J. Otolaryngol. Head Neck Surg. 2018; 70 (4): 471-476. doi: 10.1007/ s12070-018-1503-4

20. Burch H.B., Burman K.D., Reed H.L., Buckner L., Raber T., Ownbey J.L. Fine needle aspiration of thyroid nodules. Determinants of insufficiency rate and malignancy yield at thyroidectomy. Acta Cytol. 1996; 40 (6): 1176-1183. doi: 10.1159/000333977

21. Cibas E.S., Ali S.Z. The Bethesda system for reporting thyroid cytopathology. Am. J. Clin. Pathol. 2009; 132 (5): 658-665. doi: 10.1309/AJCPPHLWMI3JV4LA

22. Basharat R., Bukhari M.H., Saeed S., Hamid T. Comparison of fine needle aspiration cytology and thyroid scan in solitary thyroid nodule. Patholog. Res. Int. 2011; 2011: 754041. doi: 10.4061/2011/754041

23. Kessler A., Gavriel H., Zahav S., Vaiman M., Shlamkovitch N., Segal S., Eviatar E. Accuracy and consistency of fine-needle aspiration biopsy in the diagnosis and management of solitary thyroid nodules. Isr. Med. Assoc. J. 2005; 7 (6): 371-373.

24. Guidelines of the Papanicolaou Society of Cytopathology for the examination of fine-needle aspiration specimens from thyroid nodules. The Papanicolaou Society of Cytopathology task force on standards of practice. Mod. Pathol. 1996; 9 (6): 710-715.

25. Campbell J.P., Pillsbury H.C., 3rd. Management of the thyroid nodule. Head Neck. 1989; 11 (5): 414-425. doi: 10.1002/hed.2880110507

\section{Information about the authors:}

Chirag Pereira, Assistant Professor, ORCID: 0000-0002-3239-6631, e-mail: chiggy1989@gmail.com

Rohan Dsouza, Assistant Professor, ORCID: 0000-0002-8873-5372

Leo F. Tauro, Professor and HOD, e-mail: drlftauro@rediffmail.com

$\begin{array}{ll}\text { Received } & 22.06 .2020 \\ \text { Revision received } & 01.09 .2020 \\ \text { Accepted } & 04.09 .2020\end{array}$

